\title{
Diachronic Evidence in Nonmetric Morphological Characters of Teeth in Armenian Highland and Georgia Populations
}

\author{
A. Yu. Khudaverdyan \\ Institute of Archaeology and Ethnography National Academy of Science, Republic of Armenia, Yerevan
}

Keywords: Dental variation, biological distance

ABSTRACT The aim of the study is the assessment of biological distance between populations from Armenian highland and Georgia based on the frequency of nonmetric odontological traits. These traits are characterized by high inter-population differentiation, low sexual dimorphism, and relatively small intra and inter observer recordation error. This paper presents the results of the odontological differentiation of human populations from Armenian highland and Georgia. The comparative analysis was carried out on 12 populations. Trait frequencies for all populations were analysed using principal component analysis. Results support the following conclusions: The populations of Armenian highland and Georgia can be differentiated as far as the frequency of odontological traits are concerned. Biocultural diversity of ancient Transcaucasian populations has not been studied extensively, therefore delineating some of the patterns of phenotypic variation may be useful for understanding their ongoing evolution.

Dental anthropology, the study of modern and Central Asia (Rikushina et al., 2003; Bagdasarova, archaeologically-derived human dentitions, is a 2000), Europe (Jørgensen, 1956; Aksjanova, 1978; well-established sub-discipline of Physical Anthro- Segeda, 1993; Cucina et al., 1999; Gravere, 1999; pology. It is defined by Hillson (1996:1) as "a study Lease, 2003; Coppa et al., 2007; Vargiu et al., 2009; of people (and their close relatives) from the evi- Zubova, 2010), the Near East (Smith, 1978; Smith et dence provided by teeth." Such research yields in- al., 1987; Moskona et al., 1998), Siberia (Khaldeeva, formation on a variety of topics, including growth 1979; Tur, 2009; Zubova, 2008), Australia and development, health, diet, occupational activi- (Townsend and Brown, 1981; Townsend et al., ty, and biological affinities. This information can be 1986, 1990) and North America (Sciulli, 1998, Tochused in studies of individuals as well as populations. The analysis of nonmetric dental traits, when compared with similar studies, can be used to infer biological relationships between populations and track evolutionary variation related to changing settlement patterns. Dental morphology can provide insights into phenotypic group differences, and these may be suggestive of differences in genotypic affiliation (Varela and Cocilovo, 2000). Nonmetric dental traits are controlled in large part by genetics and are relatively free of sex and age bias (Scott and Turner, 1997). The analysis of biological relatedness using dental nonmetric traits has been helpful even in commingled samples when standardized procedures are followed (Ullinger et al., 2005). For these reasons, the reconstruction of biological relationships among ancient human groups using teeth is an important research strategy for Transcaucasian bioarcheologists. The aim of the present study is to provide new non-metric dental data for ancient Transcaucasian groups.

Several investigations provide information about nonmetric variation from a local scale in human groups from Asia and the Pacific (Hanihara, 1965, 1966; Hanihara and Minamidate, 1965; Sasaki and Kanasawa, 1998; Kitagawa, 2000), Africa (Grine, 1984, 1986, 1990; Lease, 2003), India (Lukacs, Walimbe, 1984; Lukacs, Hemphill, 1991), eri, 2002; Ullinger, 2003; Lease, 2003; Lease and Sciulli, 2005; Edgar and Lease, 2007). Surprisingly, past and present Transcaucasian populations have received little attention (Kashibadze, 1990, 2006; Palikyan, Nalban-dyan, 2006; Khudaverdyan, 2009, 2011a, b, 2013, 2014). The study of phenotypic diversity can help us understand the evolution and biocultural variation of the ancient and contemporary communities that today inhabit Transcaucasian. This will provide a more complete landscape of the dynamics that configure their gene pool.

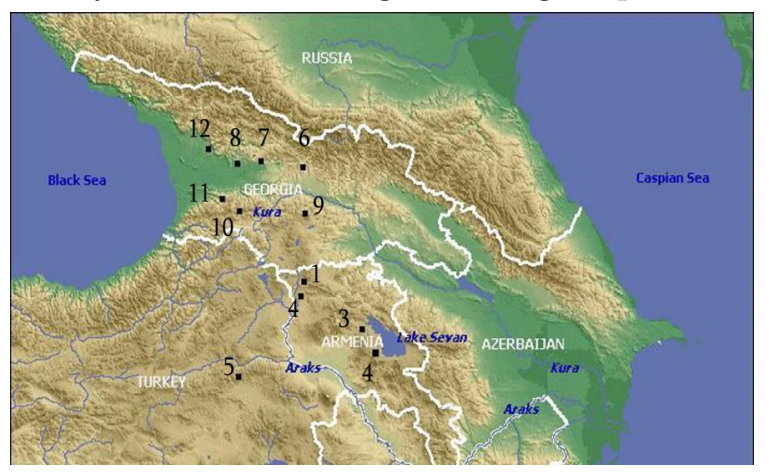

Fig. 1 Locations of Transcaucasian groups

Correspondence to:

Dr. Anahit Khudaverdyan Abhiram, Institute of Archaeology and Ethnography National Academy of Science, Republic of Armenia, Yerevan, 0025, Charents st.15 


\begin{tabular}{|c|c|c|c|c|}
\hline & Country & Sample Name & Date & Researchers \\
\hline 1 & Armenian highland & Total group: Landjik, Black Fortress & c. $4000-2000 B C$ & $\begin{array}{l}\text { Khudaverdyan, 2009, } \\
\text { 2011a }\end{array}$ \\
\hline 2 & Armenian highland & $\begin{array}{l}\text { Total group: Lchashen, Shirakavan, } \\
\text { Keti, Karchakhpyur }\end{array}$ & $\begin{array}{l}\text { c. } 2000 \mathrm{BC} \\
\text { c. } 1 \mathrm{BC}-\mathrm{AD} 3\end{array}$ & Kashibadze, 1990 \\
\hline 3 & Armenian highland & Lchashen & c. $3000-2000 \mathrm{BC}$ & Kashibadze, 2006 \\
\hline 4 & Armenian highland & $\begin{array}{l}\text { Total group: Beniamin, Vardbakh, } \\
\text { Black Fortress I, Karmrakar }\end{array}$ & c. $1 \mathrm{BC}-\mathrm{AD} 3$ & Khudaverdyan, 2009 \\
\hline 5 & Armenian highland & Bingel Dag & 20th century & Kashibadze, 2006 \\
\hline 6 & Georgia & Total group: Digomi, Mckheti & c. $3000-2000 B C$ & Kashibadze, 2006 \\
\hline 7 & Georgia & $\begin{array}{c}\text { Total group: Chiaturia, Mckheti I, } \\
\text { Mckheti }\end{array}$ & c. $1 \mathrm{BC}-\mathrm{AD} 3$ & Kashibadze, 2006 \\
\hline 8 & Georgia & $\begin{array}{l}\text { Total group: Dzinvali, Samtavro, } \\
\text { Mckheti I, Mckheti }\end{array}$ & c. VI - X AD & Kashibadze, 2006 \\
\hline 9 & Georgia & $\begin{array}{l}\text { Total group: Dzinvali, Adjaria, } \\
\text { Shatili, Adigeya, Mckheti }\end{array}$ & c. X - XII AD & Kashibadze, 2006 \\
\hline 10 & Georgia & $\begin{array}{l}\text { Total group: Dzinvali, Rustavi, } \\
\text { Sioni, Shatili }\end{array}$ & c. XIII - XIX AD & Kashibadze, 2006 \\
\hline 11 & Georgia & Total Group & Total Group & Kashibadze, 2006 \\
\hline 12 & Georgia & Dzinvali & 20th century & Kashibadze, 2006 \\
\hline
\end{tabular}

\section{MATERIALS AND METHODS}

In total, the intergroup analysis included 12 series (Table 1) from the territory of Transcaucasian (Kashibadze, 1990, 2006; Khudaverdyan, 2009, 2013, 2014) (Fig. 1). We assess dental reduction trends in two regions during three (Armenia) and four (Georgia) prehistoric transitions, Bronze Age to modern period.

I have examined 6 samples (more than 181 individuals) of Bronze and Classical periods from the territory of the Armenia. The series were grouped according to periods and local groups. The Early Bronze period (4000-3000 BC) farmer and cattle-breeder Landjik represent the KuroArexes population of the Armenian Highland. The Late Bronze period sample is represented by remains from one Armenian Highland site (Black Fortress). The combination of remains from these two sites is justified for three reasons. First, the small sample sizes for sites (Landjik, Black Fortress) were inadequate (from 10-13 individuals) for subsequent biodistance analysis. Second, the Landjik, Black Fortress sites they represent a cemetery from Shirak Plain (Table 2). Indeed, the geographic distance among sites a small. Finally, analysis of all nonmetric traits revealed no significant differences exist among remains from the two sites, so data from these sites were combined for subsequent statistical analyses (Khudaverdyan, 2009).

Remains from the Lchashen site were treated as an in- dependent sample because a sufficient number of crania from burials in Sevan pool were available for study (Kashibadze, 2006). The Bronze Age sample is represented by remains from four Armenian sites (Lchashen, Shirakavan, Keti, Karchakhpyur). Two of the four Armenian sites, i.e., Shirakavan and Karchakhpyur represent a samples with an date of 1 st century BC - 3rd century AD (i.e. ancient time) (Kashibadze, 1990, p. 287).

The Classical period (1st century BC - 3rd century AD) samples examined include remains from Beniamin, Vardbakh, Black Fortress I, and Karmracar (Table 2). The small sample sizes for sites of Vardbakh, Black Fortress I, and Karmracar were inadequate (from 12-23 individuals) for subsequent biodistance analysis. The Beniamin, Vardbakh, Black Fortress I, and Karmracar sites represent a cemetery from the Shirak Plain and the geographic distances among sites are relatively close. After the Armenian genocide, V.V. Bunak collected a large number of human skulls in 1915 that were victims of the genocide (now housed at Museum of Anthropology, Moscow). The modern population includes remains from these individuals (Bingel Dag: Armenians from Musha) (Kashibadze, 2006).

Two Bronze period samples from Georgia (Digomi, Mckheti) were analyzed in this investigation. Combining the remains from these two sites is justified because of the small number of groups (Table 2). The Classical period/ Late An-tiquity period (1st century BC - 3rd cen-tury AD) 


\begin{tabular}{|c|c|c|c|c|c|}
\hline Trait & 1 & 2 & 3 & 4 & 5 \\
\hline Midline Diastema $^{1}$ & $23.7 / 17 /$ & 2.4 & 3.6 & $10.5 / 86 /$ & 9.2 \\
\hline Dental crowding & $62.5 / 16 /$ & 1.2 & 1.8 & $78.5 / 79 /$ & 3.0 \\
\hline $\begin{array}{l}\text { Reduced, peg-formed tooth } \mathrm{I}^{2} \\
\qquad(2+3)\end{array}$ & 0.0 & 0.0 & 0.0 & $10.9 / 83 /$ & 1.0 \\
\hline Reduced, peg-formed tooth $\mathrm{I}^{2}$ & $67.5 / 15 /$ & 12.9 & 0.0 & $65.1 / 83 /$ & 19.4 \\
\hline Shovelling $\mathrm{I}^{1}$ & $35.8 / 15$ & 0.0 & 0.0 & $45.1 / 62 /$ & - \\
\hline Hypocone $\mathrm{M}^{2} \sum 3,3+$ & $37.5 / 14$ & 34.2 & 32.7 & $30.5 / 69 /$ & 40.6 \\
\hline Cara $\mathrm{M}^{1}(2-5)$ & $31.3 / 16 /$ & 43.4 & 38.7 & $46.7 / 75 /$ & 58.8 \\
\hline $\mathrm{M}_{1} 4$ & $14.3 / 15 /$ & 16.7 & 23.3 & $17.8 / 79 /$ & - \\
\hline$M_{1} 6$ & 0.0 & 2.8 & 3.3 & $5.8 / 52 /$ & - \\
\hline $\mathrm{M}_{2} 4$ & $64.7 / 17 /$ & 78.9 & 72.4 & $71.3 / 66 /$ & - \\
\hline $1 \mathrm{eo}(3) \mathrm{M}^{1}$ & $21.5 / 16 /$ & 43.4 & 38.4 & $41.94 / 31 /$ & 41.7 \\
\hline DTC & $42.5 / 18 /$ & $\begin{array}{r}7.1 \\
64\end{array}$ & 10 & $50.9 / 57 /$ & - \\
\hline DW & $42.5 / 18 /$ & 16.7 & 16.7 & $38.1 / 42 /$ & - \\
\hline 2 med II M & $29.2 / 17 /$ & 41.7 & 40.0 & $53.4 / 45 /$ & - \\
\hline
\end{tabular}

\begin{tabular}{|c|c|c|c|c|c|c|}
\hline Trait & 6 & 7 & 8 & 9 & 10 & $12^{*}$ \\
\hline Midline Diastema $^{1}$ & 4.9 & 11.4 & 3.2 & 3.2 & 5.2 & - \\
\hline Dental crowding & 1.7 & 0.0 & 4.6 & 1.2 & 1.7 & - \\
\hline $\begin{array}{l}\text { Reduced, peg-formed tooth } \\
\qquad \mathrm{I}^{2}(2+3)\end{array}$ & 3.6 & 0.0 & 0.0 & 0.32 & 0.0 & - \\
\hline $\begin{array}{l}\text { Reduced, peg-formed tooth } \\
\qquad \mathrm{I}^{2}(1)\end{array}$ & 8.2 & 0.0 & 0.0 & 0.0 & 0.0 & - \\
\hline Shovelling $\mathrm{I}^{1}$ & 15.5 & 7.1 & 7.7 & 4.0 & 33.4 & - \\
\hline Hypocone $\mathrm{M}^{2} \sum 3,3+$ & 10.3 & 23.8 & 25.7 & 20.6 & 32.9 & 33.3 \\
\hline Cara $M^{1}(2-5)$ & 47.1 & 43.8 & 28.6 & 36.7 & 60.1 & 100.0 \\
\hline $\mathrm{M}_{1} 4$ & 9.7 & 10.8 & 11.8 & 8.92 & 5.1 & 66.7 \\
\hline $\mathrm{M}_{1} 6$ & 4.9 & 5.4 & 0.0 & 6.5 & 2.3 & 0.0 \\
\hline $\mathrm{M}_{2} 4$ & 87.6 & 93.0 & 83.6 & 93.3 & 95.0 & 100.0 \\
\hline 1 eo (3) $M^{1}$ & 78.62 & 33.3 & 25.0 & 38.8 & 40.5 & - \\
\hline DTC & 8.9 & 0.0 & 0.0 & 6.6 & 2.1 & - \\
\hline DW & 18.5 & 28.5 & 8.3 & 7.5 & 0.0 & - \\
\hline $2 \operatorname{med}$ II $\mathrm{M}_{1}$ & 14.8 & 33.3 & 12.5 & 17.5 & 12.5 & - \\
\hline
\end{tabular}


samples from Georgia exam-ined by this study include remains from Chiaturia, Mckheti I, Mckheti I (total group). Inadequate number of remains were available from this site and, there-fore, they were analyzed as a single sam-ple. Four Early Feudal period samples from Georgia (Dzinvali, Samtavro, Mckheti I, Mckheti / total group/) were analyzed. Average Feudal period (c. $X$ - XII AD) samples examined include remains from Dzinvali, Adjaria, Shatili, Adigeya and Mckheti. Late Feudal period (c. XIII - XIX AD) samples examined include remains from Dzinvali, Rustavi, Sioni and Shatili. The modern population includes remains from Dzinvali (Kashibadze, 2006).

Human dentitions exhibit highly heritable nonmetric morphological crown and roots traits that vary within and between populations. The term non-metric implies structural variations of individual crown and root forms that are visually scored in two ways: "presence-absence" characters such as furrow patterns, accessory ridges, supernumerary cusps and roots, or, as differences in form such as curvature and angles (Hillson, 1996; Scott and Turner, 1997; Zubov, 1973, 1979). Numerous studies have demonstrated that morphological dental forms respond to microevolutionary forces of admixture (e.g. Turner, 1969; Pinto-Cisternas et. al., 1995; Khudaverdyan, 2011), mutation (e.g. Morris et al., 1978), genetic drift (e.g. Turner 1969; Scott and Dahlberg, 1982; Segeda, 1993; Khudaverdyan, 2009, 2013, 2014; Vargiu et al., 2009; Zubova, 2008, 2010), and selection (e.g. Dahlberg, 1963; Scott and Turner, 1988), thus evincing their high degree of genetic control.

The method A.A. Zubova (1973, 1974), the most widely employed system in Russian school of anthropology, was used to score non-metric dental traits. These traits are characterized by high inter-population differentiation and the analysis of their occurrence enables researchers to obtain data concerning the genetic relationships between populations identified as falling in different ethnic complexes. Odontological traits are used successfully in the description and explanation of both evolutionary and microevolutionary processes. Such studies are commonly used to assess specific research questions such as the synchronic biological relatedness of segments of a particular society (e.g. Johnson and Lovell, 1994), or diachronic changes in trait expressions in a particular region (e.g. Lukacs and Hemphill, 1991; Cucina et al., 1999; Gravere, 1999; Coppa et al., 2007). Since teeth complete their growth during the early stages of an individual's development, they are strongly determined be genes and their morphological structures are only slightly sensitive to environmental influences. Teeth are usually well preserved in archaeological materials and are often the only source of observation of human remains.
The following odontological traits were used in this comparative analysis: (1) diastema of I1-I1, (2)crowding of I1; (3)shovelling of I1; (4) reduction of I2 (grades 2+3); (5) reduction of I2 (grade 1); (6) reduction hypocone (forms $3+$ and 3 ) of the upper second molar; (7) Carabelli's cusp on M1; (8) form 1 pa (eo) on M1; (9) fourcusped forms on M1; (10) fix-cusped forms on M1; (11) four-cusped forms on M2; (12) deflecting wrinkle of the metaconid of M1; (13) the variant 2 med II position of the second furrow of the metaconid on M1; and (14) distal crest of trigonid on M1 (Table 3).

The above-mentioned traits were selected because they meet the following criteria:

1) the traits should not reveal inter-correlations for the frequency of occurrence;

2) they should reveal high inter-group variability;

3) the degree of variant formation cannot change with an individual's age,

4) it should be easy to find comparative data for different populations.

Data are subjected to the component (factor) and cluster analysis. A.G. Kozintseva and B.A. Kozintseva's statistical package was used (Museum of Anthropology and Ethnography of name of the Peter the Great, St. Petersburg).

\section{RESULTS AND DISCUSSION}

\section{Secular dental changes in the populations of the Trans-} caucasian

Diachronic tendencies in cranial and dental morphology have occurred ever since anatomically modern humans began to populate the planet. One of the major tendencies was the increase of body length. Cranially, one of the most important trends was brachycephalization (Alexeev, 1974). Apart from those tendencies, irregular fructuations in body size occurred, whereas the overall proportions displayed greater stability (Godina et al., 2000). A secular increase in body length observed over most of the 20th century was not exceptional. Dental changes are related to somatic ones. Certain aspects of dentition are rather labile, as evidenced by various patterns of the gracilization process, which is probably continuing. While brachycephalization (or debrachycephalization), gracilization, dental reduction, and the increase of body length may occur in parallel, the causes of those processes probably vary. Microevolutionary tendencies may be triggered by ontogenetic changes, specifically acceleration or deceleration of growth caused by endocrine, neurohumoral, trophic, and other factors. With our taking into account the secular changes in the dentition, an adequate reconstruction of population history is hardly possible, especially when issues of continuity versus replacement are discussed. Secular 


\begin{tabular}{|c|c|c|c|}
\hline Trait & Tooth & Trait definition used in this study (Zubov 1968) & $\begin{array}{c}\text { Matching ASU Dental An- } \\
\text { thropology System and } \\
\text { Zubov system ASU=Zubov }\end{array}$ \\
\hline Midline Diastema & UI1 & $\begin{array}{c}\text { space between the upper central incisors equal or larger } \\
\text { than } 2 \mathrm{~mm} ; 0 \text { - no diastema, space }\end{array}$ & $0=0 ; 1=1$ \\
\hline Dental crowding & UI2 & $\begin{array}{l}\text { crowding of the upper lateral incisors; } 0 \text { - crowding is not } \\
\text { observed; } 1 \text { - crowding is observed }\end{array}$ & $0=0 ; 1=1$ \\
\hline Shovelling & UI1 & $\begin{array}{l}\text { shoveling of the upper central incisors; observed when the } \\
\text { marginal ridges of the incisors are prominent and enclose } \\
\text { a deep fossa in the lingual surface of the tooth: } 0 \text { - none; } 1 \\
\text { - poorly delineated rollers along edges; } 2 \text { - well differenti- } \\
\text { ated ridges on both sides, somewhat projecting above the } \\
\text { surface; } 3 \text { - clearly expressed high ridges on the lingual } \\
\text { surface giving the characteristic shovel- shaped form }\end{array}$ & $0=0 ; 1=1 ; 2=2 ; 3-6=3$ \\
\hline $\begin{array}{l}\text { Reduced, peg-formed } \\
\text { tooth }\end{array}$ & UI2 & $\begin{array}{l}\text { Distal lobe of second incisors reduced enough to produce } \\
\text { a peg-shaped form; } 0 \text { - no reduction, lateral incisor width } \\
\text { approximately } 70 \text { to } 80 \% \text { that of central incisor; } 1 \text { - lateral } \\
\text { incisor mesial-distal width approximately } 50 \% \text { that of } \\
\text { central; } 2 \text { - conical incisor with a pointed apex; } 3 \text { - peg- } \\
\text { form tooth, crown height considerably less than adjacent } \\
\text { tooth }\end{array}$ & $2=2+3$ \\
\hline $\begin{array}{l}\text { Reduced, peg-formed } \\
\text { tooth }\end{array}$ & UI2 & Please follow above sample & $0=0 ; 1=1$ \\
\hline Hypocone & UM2 & $\begin{array}{l}\text { degree of reduction of the hypoconus on the second upper } \\
\text { molars; } 4 \text { Hypocone well developed, forming a distinct } \\
\text { disto-lingual corner of the crown, } 4-\text { Hypocone dimin- } \\
\text { ished, not forming a corner, } 3+\text { Hypocone very reduced, } 3 \\
\text { Absence of hypocone }\end{array}$ & $3.5,3=4$ \\
\hline Carabelli's cusp & UM1 & $\begin{array}{l}\text { the small additional cusp on the mesiolingual corner of the } \\
\text { upper first molar presents in a variety of different forms; } 0 \\
\text { Absence, } 1 \text { Slightly uneven surface due to one or two } \\
\text { barely visible grooves, } 2 \text { Slight swelling limited from the } \\
\text { mesial and occulusal sides by a curved weakly expressed } \\
\text { groove, } 3 \text { Groove has character of a cusp, } 4 \text { Cusp clearly } \\
\text { expressed, } 5 \text { Large free-standing cusp }\end{array}$ & $0=0 ; 1=1 ; 2=2 ; 3-5=3$ \\
\hline 1 pa (eo) 3 & UM1 & $\begin{array}{l}\text { type of structure of the first furrow of the paracone on the } \\
\text { first upper molar }\end{array}$ & $\begin{array}{l}\text { Trait not used in the ASU } \\
\text { System }\end{array}$ \\
\hline Four-cusped & LM1 & $\begin{array}{c}\text { Cusp number mandibular molars } 44 \text { is highest number of } \\
\text { cusps }\end{array}$ & $4=4$ \\
\hline Four-cusped & LM2 & 44 is highest number of cusps & $4=4$ \\
\hline Six-cusped & LM1 & 66 is highest number of cusps & $6=6$ \\
\hline Deflecting wrinkle & LM1 & $\begin{array}{l}\text { The deflecting wrinkle is one of the particular formations } \\
\text { of the median ridge of the metaconid. The ridge, when the } \\
\text { deflecting wrinkle appears, shows a stronger development } \\
\text { in either its length or breadth and curves distalward at the } \\
\text { central part of the occlusal surface. }\end{array}$ & $0-1=0$ \\
\hline 2med II & LM1 & $\begin{array}{l}\text { the variant } 2 \text { med II position of the second furrow of the } \\
\text { metaconid }\end{array}$ & $\begin{array}{l}\text { Trait not used in the ASU } \\
\text { System }\end{array}$ \\
\hline Distal Trigonid Crest & LM1 & $\begin{array}{l}\text { This trait is characterized by a crest or ridge that courses } \\
\text { buccolingually along the distal aspect of the primitive } \\
\text { trigonid, represented by the protoconid and metaconid. It } \\
\text { often appears as an extension of the distal accessory ridge } \\
\text { of the protoconid although the distal accessory ridge of the } \\
\text { metaconid may also be involved in forming the crest. }\end{array}$ & $0-1=0$ \\
\hline
\end{tabular}

Table 3. Non-metric dental traits definitions and code matching for the ranked traits used in this study (Zubov scheme) and in the Arizona State University Dental System (ASU scheme) cited according to Haeussler and Turner (1992): 277-278 
changes in dentition over the last few centuries and millennia have been studied in various countries. A diachronic dental crown size reduction has been observed among Middle, Late and Post-Pleistocene hominid palaeo-populations and modern human populations (Brace, 1976, 1979, 1980; Brace and Mahler, 1971; Brace et al., 1987; Brose and Wolpoff, 1971; Wolpoff, 1971; Smith, 1977; Frayer, 1977, 1978, 1984; y'Edynak, 1989; Chamla, 1980; Calcagno, 1986; Calcagno and Gibson, 1988; Keiser, 1990; Pinhasi, 1998). Various researchers report that this trend varies by tooth type and tooth dimension (Brace et al., 1987; Wolpoff, 1971; Frayer, 1978, 1984).

It has long been suggested that these changes might be caused by the transition to soft food (Dutta, 1983) and the ensuing reduction of functional load. Comparative studies of twins (Potter et al., 1976), of parent and offspring (Goose, 1971) and full versus half siblings (Townsend and Brown, 1978) substantiate the claim that more than half the variability in tooth crown size could be attributed to genetic factors (Brabant and Twiesselmann, 1964; Townsend and Brown, 1978; Scott and Turner, 1997). Other experts point to the importance of environmental or biochemical processes, etc. (Dahlberg, 1963; Shapiro, 1963). Dahlberg (1963) observed considerable population-specific variability in tooth size and form, so he hypothesized that changes in the human dentition are the result of a relaxation of certain environmental pressures. He therefore proposed that European populations have a smaller tooth mass than do populations in "less favoured environments." Small teeth may be the outcome of "selection by crowding," whereby reduced load on the masticatory apparatus causes the eduction of alveolar processes, resulting in too little space for teeth (Zubov and Khaldeeva, 1989). Brace (1963) presented the Probable Mutation Effect theory (PME) that suggests that in the absence of natural selection, mutations will be the main force acting toward a reduction of structural size and complexity of teeth and other organs. Thus, developmental processes, controlled by complex genetic mechanisms, will be disrupted resulting in an incomplete or a simplified dental structure (such as the change in cusp pattern). The PME is based on the concept of drift and stochastic microevolutionary mechanisms that act in the absence of selection (Sciulli and Mahaney, 1991). Another possible factor in dental gracilization may be the high occurrence of caries, which mostly affects large teeth with complex occlusal surfaces (Khudaverdyan, 2005). These processes demonstrate the importance of cultural factors in dental evolution. Transition to agriculture may lead to a reduction of dental size, as demonstrated by P. Sciulli (1979), who compared the dentition of hunters and gatherers with that of agriculturalists. It has been demonstrated that the Neolithic Revolution may have caused an abrupt decrease in tooth size. According to D. Frayer (1977), the dimensions of the facial skeleton during the Upper Paleolithic and Mesolithic in Europe decreased more rapidly than did the size of teeth.


Fig. 3. Ranges of dental non-metric traits in samples from Armenian Highland (1) and Georgia (2) in Bronze Age: 1 - I ${ }^{1}-\mathrm{I}^{1}$ diastema, 2 - $\mathrm{I}^{2}$ crowding, 3 - I $\mathrm{I}^{2}$ reduction (grades $2+3$ ), 4 - I $\mathrm{I}^{2}$ reduction (grade 1), 5 - double shoveling, 6 - hypocone reduction on $\mathrm{M}^{2}, 7$ - Carabelli cusp on $\mathrm{M}^{1}, 8$ - four-cusped $\mathrm{M}_{1}, 9$ - six-cusped $\mathrm{M}_{1}, 10$ - fourcusped $M_{2}, 11$ - 1eo (3) $M^{1}, 12$ - distal ridge of trigonid, 13 - deflecting wrinkle of metaconid, 14 - 2 med II

Dental reduction in the Near East over the last six thousand years was quite pronounced (Smith, 1976). As P. Smith has shown, the direction of the microevolutionary process was the same, and differences between the Near Eastern groups were mainly due to various rates of this process and to isolation. Dental reduction, therefore, can lead not only to the decrease of between-group variation, but also to an increase. The objective of this study is to compare prehistoric and recent populations of the Transcaucasian to trace secular changes in dental morphology. Information about the southern gracile dental types can be found in Zubov (1979). The southern gracile type has low percentages of Carabelli's trait, somewhat increased frequencies for the distal trigonid crest, M14, M24 and low variant 2 med (Khaldeeva, 1992). The southern gracile type is characteristic for 
peoples of the Transcaucasian (Kochiev, 1979; Bronze Age population of Georgia (Fig. 4-1). In the Kashibadze, 1990, 2006; Khudaverdyan, 2009, 2011, Classical period, it drops to $(10.5 \%)$, and in moderm 2013, 2014), Daghestan (Gadjiev, 1979) and Bulgaria Armenians the occurrence remains low (9.2\%). The ten(Minkov, 1979). The 14 traits, their frequencies, and the number of individuals observed for each trait for the dency, therefore, is quite pronounced. The frequency of Armenian Highland and Georgia samples are provided in Table 2. The differentiation which can be traced in Transcaucasian populations is demonstrated Figures 2 and 3 . In the following, patterns of dental reduction in populations of the Transcaucasian are described.

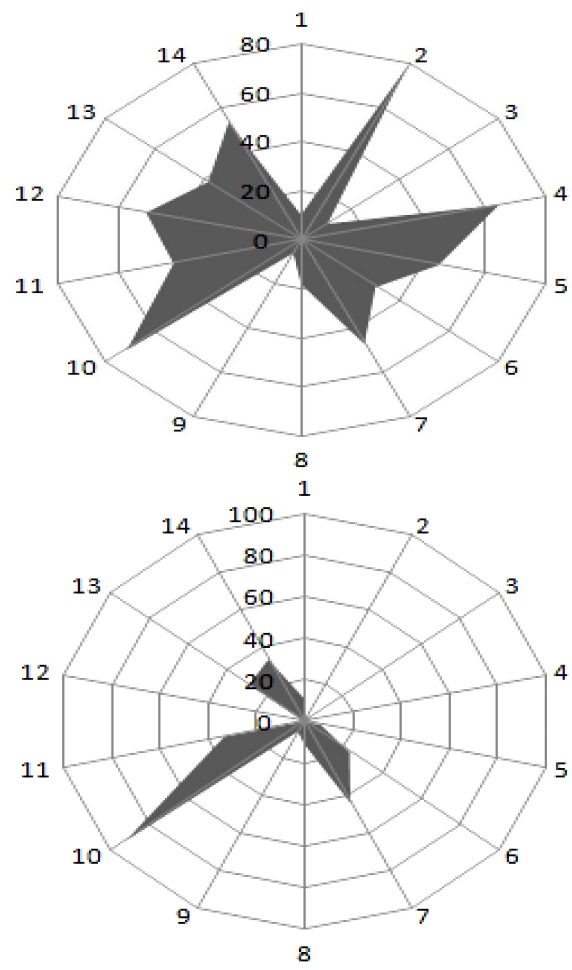

Fig. 4. Ranges of dental non-metric traits in samples from Armenian Highland (1) and Georgia (2) in Ancient Age:

1 - I1-I1 diastema, 2 - I2 crowding, 3 - I2 reduction (grades 2+3), 4 - I2 reduction (grade 1), 5 - double shoveling, 6 - hypocone reduction on M2, 7 - Carabelli cusp on

M1, 8 - four-cusped M1, 9 - six-cusped M1, 10 - fourcusped M2, 11 - 1eo (3) M1, 12 - distal ridge of trigonid,

\section{Diastema}

A "diastema" is a dental term referring to a space or gap between two teeth, and its size depends on that of the alveolar process (Zubov, 1973). It is most commonly applied to the space between the two maxillary central incisor teeth (upper front teeth: I1-I1). The secular decrease in the frequency of this trait reflects one of the aspects of dental reduction. The frequency of diastema in the Bronze Age populations of the Armenian Highland ranges from $2.4 \%$ to $23.7 \%$. It is rather low in the diastema in the Classical period and Feudal Age populations of the Georgia ranges from $3.2 \%$ to $11.4 \%$.

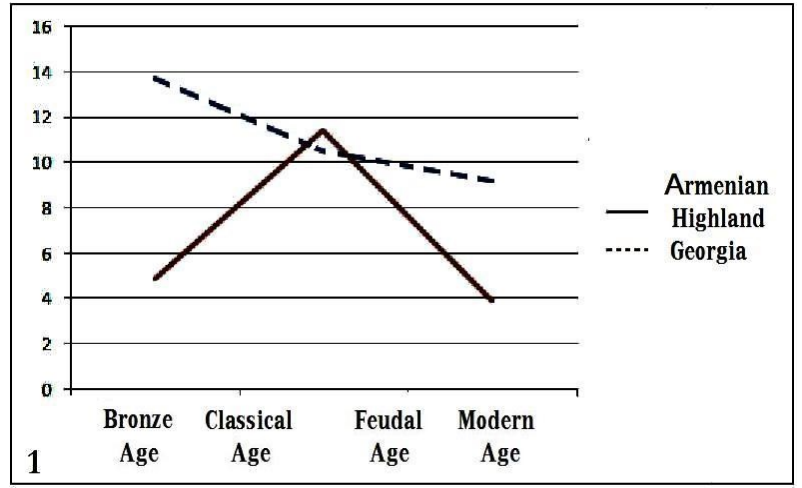

Fig. 4-1. Diastema (I1-I1) in samples from Armenian Highland and Georgia

\section{I2 crowding}

Crowding (mainly that of incisors) is an anomaly in the position of teeth, being a phenotypic dental response to jaw size reduction. Crowding occurs when there is disharmony in the tooth-to-jaw size relationship or when the teeth are larger than the available space. Although crowding is morphologically opposed to the diastema, the secular tendencies in these traits are not necessarily opposed; in fact, they sometimes occur in parallel. The frequency of lateral maxillary incisor crowding in populations of the Armenian Highland ranges from $1.2 \%$ to $78.5 \%$. It was high in Classical period people of Beniamin, Black Fortress I, Vardbakh, and Karmrakar. The drop of frequency to $3 \%$ in 20 th century Armenians is rather unusual. Crowding of the teeth in Early Feudal Age Georgia is higher than in the Bronze Age. It is rare in Georgian populations (Fig. 4-2).



Fig. 4-2. Crowding (I2) in samples from Armenian Highland and Georgia 


\section{I2 reduction}

Lateral incisors are frequently smaller than medial ones. Maximal reduction of the lateral maxillary incisors, ultimately resulting in peg-shaped incisors, was rare of the Transcaucasian. A small increase of frequency of grades $2+3$ is observed in the Classical period from Armenian Highland (10.9\%) and in the Bronze Age from Georgia $(3.6 \%)$.

Grade 1 reduction (Fig. 4-3) was frequent during the Bronze Age (Landjik, Black Fortress) and the Classical period (Beniamin, Vardbakh, Black Fortress I, Karmracar) in populations of the Armenian Highland. Its low frequency $(19.4 \%)$ is observed in modern (20th century) Armenians. Whereas the frequency of reduction (grade 1) in the Bronze Age people of Georgia is $8.2 \%$, not a single case has been registered from burials of the Classical period and Feudal Age.

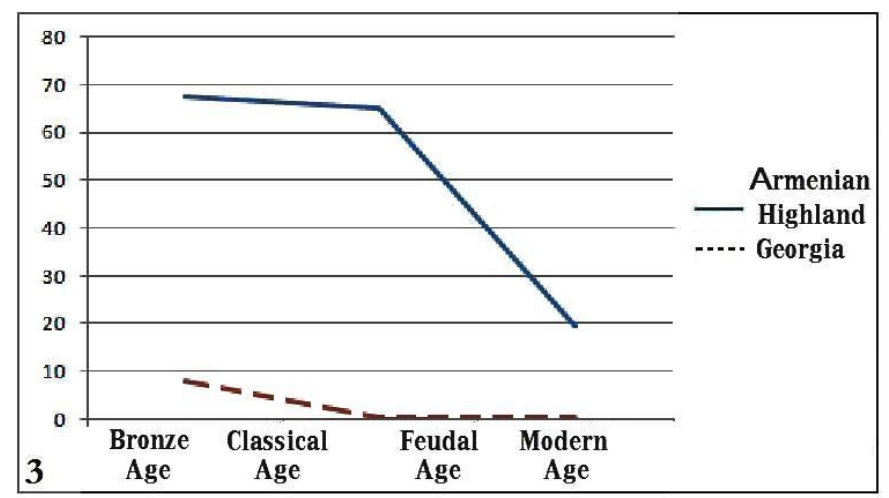

Fig. 4-3. I2 reduction in samples from Armenian Highland and Georgia

\section{Double shoveling}

Shoveling is a combination of a concave lingual surface and elevated marginal ridges enclosing a central fossa in the upper central incisor teeth. The mesial and distal lingual ridges of the incisors may be elevated producing a 'shovel-shaped' incisor. This trait is quite variable on the world scale and displays clear-cut geographical regularities. According to A. Zubov (1973), evolutionary tendencies are quite different: in Eastern groups, the trait remained stable or tended to become more common, while the frequencies of the shoveling gene in the West decreased markedly and in a regular fashion. At present, the frequency of the shoveling gene in the West appears to continue dropping, making the East-West differences even more pronounced (Zubov, 1973). This process is counterbalanced by admixture. In the Bronze Age from Armenian Highland, the mean total shoveling frequency is 35.8, and it increases in Classical period (45.1\%). People of the Classical period exhibit the highest frequency possibly evidencing admixture. It was high and in Late Feudal Age people of Georgia (33.4\%).

In Classical times (1st century BC - 3rd century AD) in the Caucasus, there was interaction between different ethno-cultural units - Iranian-speaking nomads (Scythians, Sarmatians, Sauromatians, Saka) (Herodotus IV; Strabo XI; Piotrovskii, 1959) and local populations. The advancement of the Scythians, Sarmatians and Saka in the territory of Transcaucasia was accompanied by not only an interaction of various cultural elements, but also admixture. The invasions of various tribes led, in stages, to a mixture of outsiders among the native Armenians and a dilution of their ranks on the plateau. The artificial modification of skulls (such as bregmatic, ring deformations of a head was known in the ancient population of the Beniamin, Shirakavan and Karmrakar, Vardbakh) and teeth in Ancient peoples of the Armenian Highland may be related to emerging social complexity and the need to differentiate among people, creating a niche for highly visual bodily markers (Khudaverdyan, 2011c).

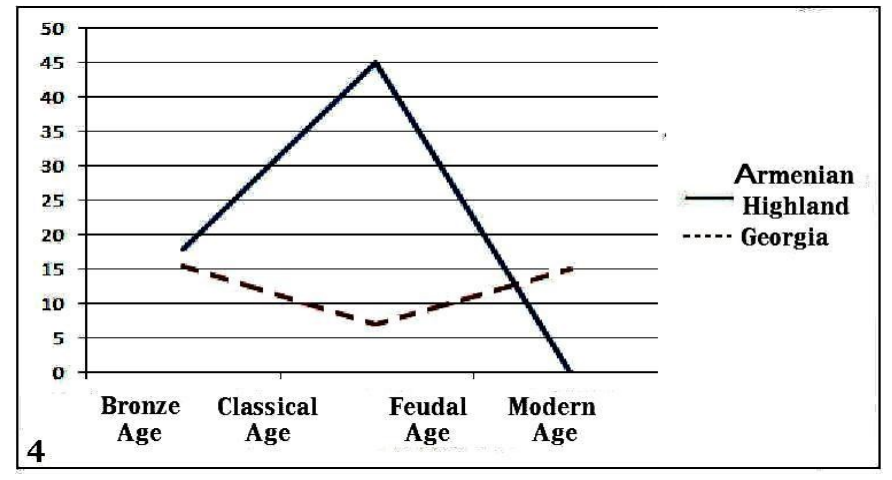

Fig. 4-4. Double shoveling in samples from Armenian Highland and Georgia

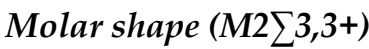

Hypocone (distolingual cusp) reduction of maxillary second permanent molar. Dahlberg's diagrams of degrees of cusp reduction were used for recording hypocone expression (Zubov, 1973). The total occurrence of reduced forms $3+$ and 3 of the upper second molars gradually increases from the Bronze Age to the 20th century. In the Armenian Highland, a distinctive feature of the Bronze Age populations is a relatively high frequency of hypocone reduction on the upper second molar; later, the trait becomes less frequent in groups of the Classical period. The population of Shirakavan and Karchakhpyur (Armenia, Classical period) is also characterized by a very high of reduction of the hypocone on M2 (45,8\%) (Palikyan, Nalbandyan, 2006). Its highest frequency is observed in modern (20th century) Armenians (Fig. 4-5).

In people of the Georgia the range of variation is considerable: Bronze Age (10.3\%), Classical period (23.8\%), Early Feudal Age (c. VI - X AD) (25.7\%), Middle Feudal Age (c. X - XII AD) (20.6\%); Late Feudal Age (c. XIII - XIX AD) $(32.9 \%)$, and modern Georgians (20 century) (33.3\%). The trait, therefore, is temporally unstable, and its variation is rather erratic. 




Fig. 4-5. Molar shape in samples from Armenian Highland and Georgia

\section{Carabelli cusp on the upper first molar}

Carabelli's trait is a morphological feature that is expressed on the protocone of human maxillary molars. It is a quasicontinuous variable, i.e. it can be either present or absent, but when present, it exhibits continuous variation in expression (Sofaer, 1970). The expression of the trait varies from a slight or distinct single furrow, pit, double furrow, y-shaped furrow, or slight protuberance lacking a free apex, to a small, moderate, or large cusp, which occasionally equals in size the main occlusal cusp. A pit and a furrow (single, double, y-shaped) are negative expressions of the trait, whereas a protuberance and a cusp are positive expressions (Alvesalo et al., 1975). Certain researchers have noted the frequency of this trait has increased over the last centuries (Brabant and Twiesselmann, 1964; Donina, 1969).

A similar tendency is observed in Armenian Highland groups (Bronze Age: 31.3 - 43.4\%; Classical period: $46.7 \%$, moderm Armenians: $58.8 \%$ ). In people of the Georgia the variation range is considerable: Bronze Age 47.1\%, Classical period $43.8 \%$, Early Feudal Age (c. VI X AD) 28.6\%, Middle Feudal Age (c. X - XII AD) 36.7\%; Late Feudal Age 60.1\%, modern Georgians 100\%.

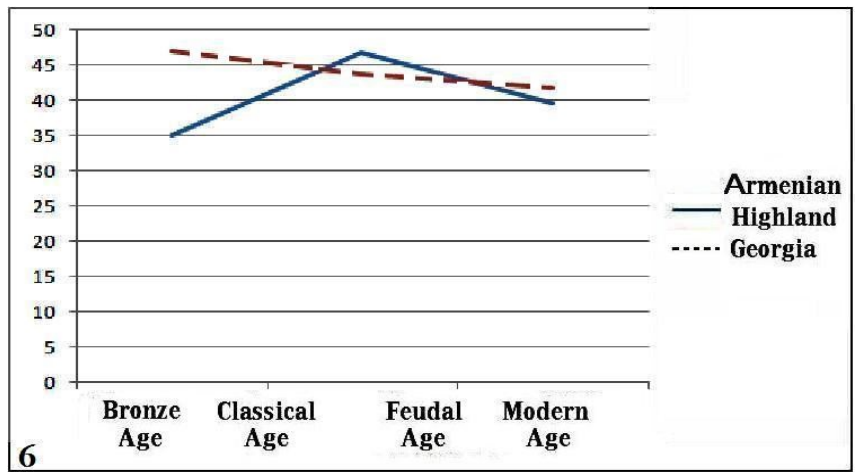

Fig. 4-6. Carabelli cusp in samples from Armenian Highland and Georgia

\section{Number of cusps on the lower molars}

The occurrence of four-cusped lower first molars in the Bronze Age population of the Armenian Highland ranges from14.3 - 23.3\% (Fig. 4-7). People of the burial from Lchashen exhibit the highest frequency. In people of the Classical period of the Armenian Highland the mean total four-cusp score is $17.8 \%$. The frequencies of four-cusp LM1 in populations of Georgia range from $5.1 \%$ to $66.7 \%$. Its highest frequency is observed in modern Georgians (Dzinvali).

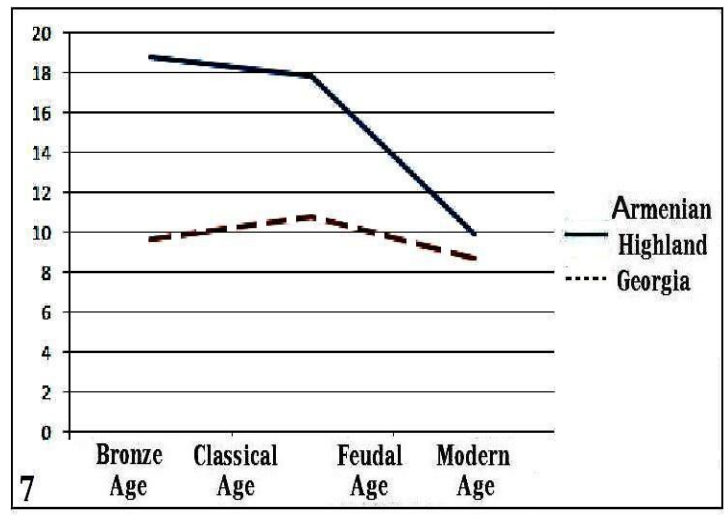

Fig. 4-7. Four-cusp lower first molars in samples from Armenian Highland and Georgia

In populations of the Armenian Highland, the frequency of the four-cusped lower second molars tends to increase over time. People of the Georgia display a high degree of lower second molar cusp reduction (Fig. 4-8).

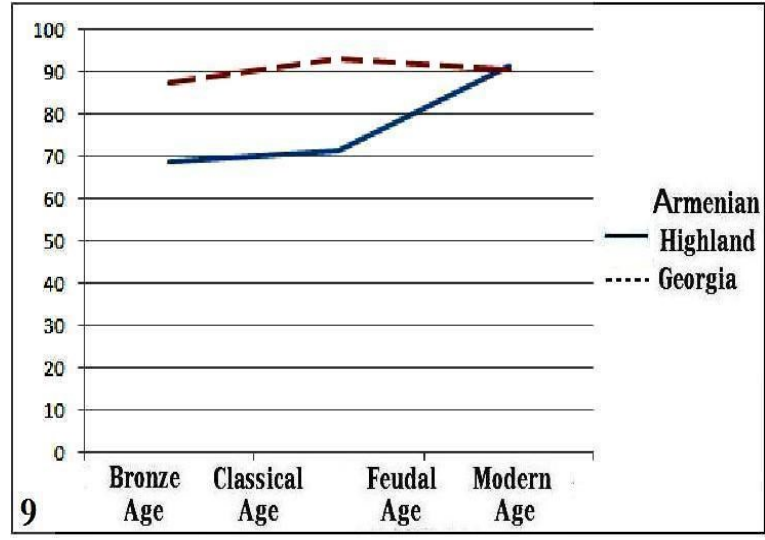

Fig. 4-8. Four-cusp lower second molars in samples from Armenian Highland and Georgia

The frequency of the sixth-cusp on the lower first molar is low in nearly all populations of the Transcaucasian. The trait is virtually absent in the Bronze Age population (Landjik, Black Fortress) of the Armenian Highland and Early Feudal Age of the Georgia (Fig. 4-9). People of the Classical period of the Armenian Highland (5.8\%) 
and Middle Feudal Age of the Georgia (6.5\%) exhibit the highest frequencies of the sixth cusp.

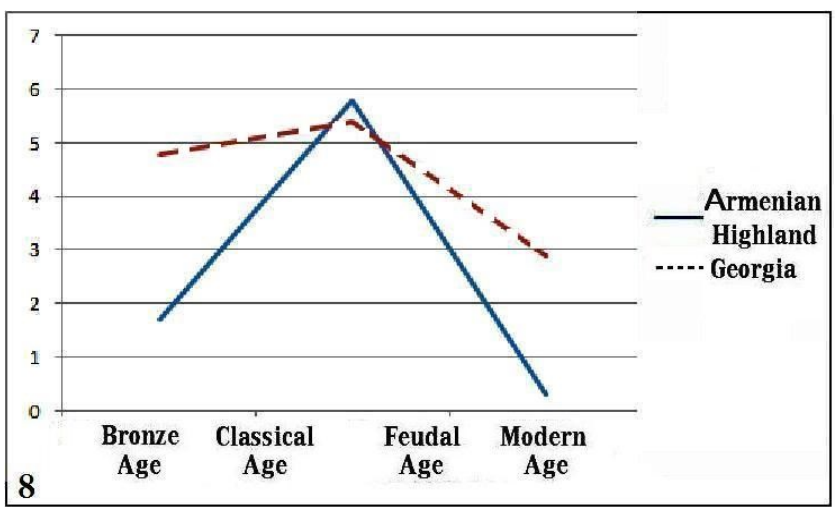

Fig. 4-9. Sixth-cusp lower first molars in samples from Armenian Highland and Georgia

Type 3 of the first eocone groove on the upper first molar (1 eo (3) on M1)

The frequency of type 3 of the first eocone groove on the upper first molar in populations of the Bronze Age Armenian Highland ranges from $21.5 \%$ to $43.4 \%$. The population of the Classical period $(41.94 \%)$ and the early 20th century Armenian series described in Bingel Dag $(41.7 \%)$ reveals rather similar frequencies (Fig. 4-10). Populations of the Bronze Age display a high degree of type 3 of the first eocone groove on the upper first molar. The trait becomes less frequent in groups of the Classical period $(33.3 \%)$ and even rarer in Early Feudal Age samples (25.0\%).

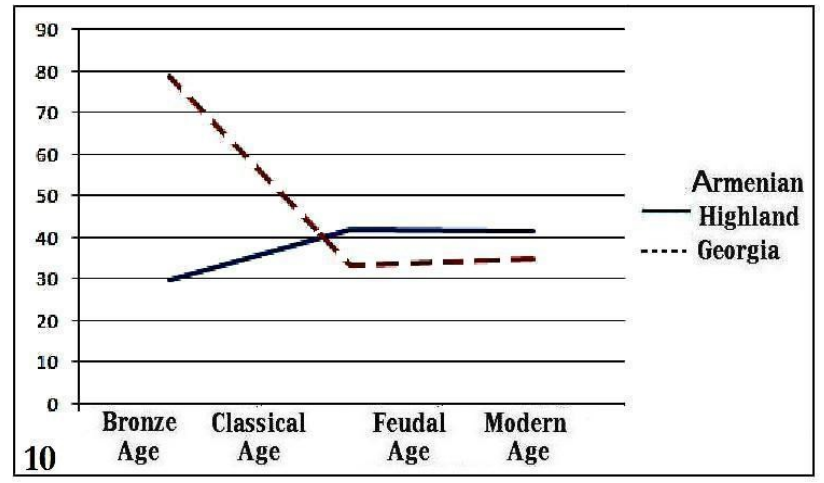

Fig. 4-10. Type 3 of the first eocone groove on the upper first molar in samples from Armenian Highland and Georgia

\section{Distal trigonid crest (DTC)}

This trait is ancient and stable. Some specialists believe it is highly diagnostic (Zubov, 1973, 1979; Khaldeyeva, 1992). Discrete dental traits are under genetic control (Nichol, 1990; Scott, 1973; Scott and Turner, 1997) and can be used to estimate genetic relationships among populations (Coppa et al., 2007; Haydenblit, 1996; Howell and Kintigh, 1996; Irish, 2005, 2006; Scott and Turner, 1988, 2006; Sofaer et al., 1986). The frequency of distal trigonid crest in populations of the Bronze Age Armenian Highland ranges from $7.1 \%$ to $42.5 \%$. In the Classical period from the Armenian Highland, the frequency of the distal trigonid crest is 50.9; it decreases in 20th century Armenians (Fig. 4-11). People of Georgia display a low incidence of the distal trigonid crest (Bronze Age 8.9; Middle Feudal Age (c. X - XII AD) 6.6 \%; Late Feudal Age 2.1\%).

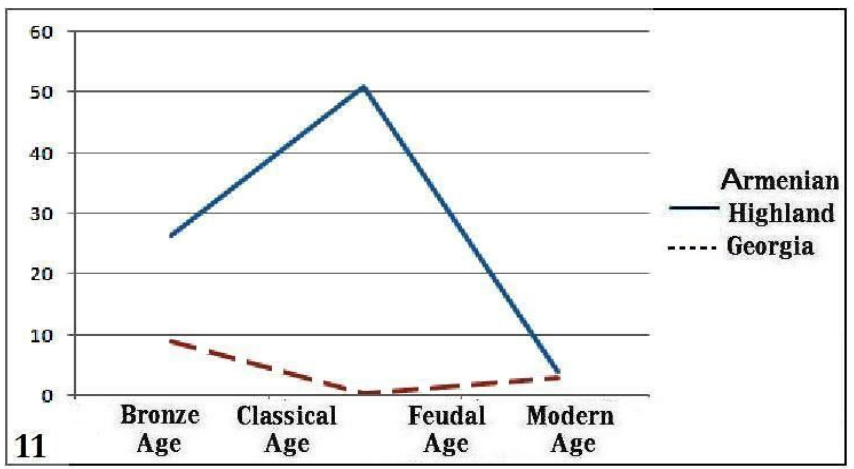

Fig. 4-11. Distal trigonid crest in samples from Armenian Highland and Georgia

\section{Deflecting wrinkle of metaconid (DW)}

The deflecting wrinkle is a particular formation of the median ridge of the metaconid. When the deflecting wrinkle is present, the median ridge shows a stronger development in either its length or breadth and curves distalward at the central part of the occlusal surface. This character was first described by F. Weidenreich (1937) in his papers on Sinanthropus and Gigantopithecus, and subsequently, von G.H.R. Koenigswald (1952) drew attention to the deflecting wrinkle in the deciduous mandibular molars in modern Javanese.

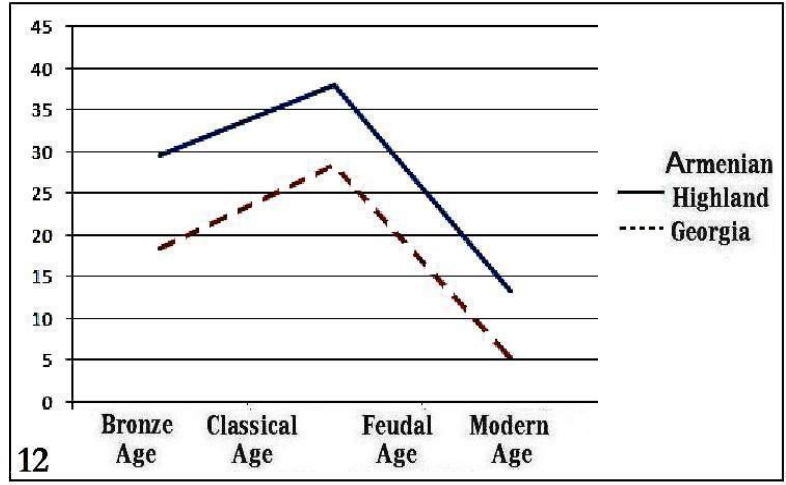

Fig. 4-12. Deflecting wrinkle of metaconid in samples from Armenian Highland and Georgia 
In addition, the frequency distribution of this character in Japanese permanent molars was reported by M. Suzuki and T. Sakai (1956) and in Japanese permanent and deciduous molars by K. Hanihara et al, (1964) and K. Hanihara (1970).

In Bronze Age Armenians (Landjik, Black Fortress, $42.5 \%)$, the frequency of the deflecting wrinkle of metaconid is higher than Classical period (38.1\%). It was low in Bronze Age people of Georgia (18.5\%), being maximal in the Classical period (28.5\%) (Fig. 4-12). Interestingly, the frequency of the deflecting wrinkle in Early Feudal Age $(8.3 \%)$ and Middle Feudal Age samples $(7.5 \%)$ is low.

\section{2(II) med}

2(II) med is the notation for an odontoglyphic trait on the metaconid (med) of lower molars. 2 (II) indicates that furrow 2 (a second order furrow that occurs closer to the fovea centrale than furrow 1) goes into furrow II (a first order furrow that separates the protoconid from the metaconid) (Zubov, 1973).

The frequency of 2(II) med in populations of the Bronze Age Armenian Highland ranges from 29.2\% to $41.7 \%$. In a Classical period sample from the Armenian Highland, the 2(II) med frequency is 53.4. The trait is low in a Bronze Age population in Georgia (14.8\%). In Classical period Georgia, the frequency of the 2(II) med is 33.3, and it decreases in Feudal Age (Early Feudal Age $12.5 \%$, Middle Feudal Age $17.5 \%$; Late Feudal Age $12.5 \%$ ).



Fig. 4-13. 2(II) med in samples from Armenian

Highland and Georgia

Figures 2 and 3 presents the differentiation of the comparative populations from Armenian Highland and Georgia (Bronze Age and Classical period). Teeth of the population from Armenian Highland (Bronze Age) are characterized by a low frequency of Carabelli's cusp on M1, a low frequency of six-cusped forms on M1. and the 1eo (3) on $\mathrm{M}^{1}$. The occurrence of pronounced reduction of upper second incisors was not recorded (variants 2 and 3). The frequency of crowding, diastema, reduc- tion of incisors (grade 1), hypocone reduction of maxillary second permanent molar (M2 $23,3+)$, four-cusp lower first molars, distal ridge of trigonid and deflecting wrinkle of metaconid was very high (Fig. 2). Teeth of the population from Georgia (Bronze Age) are characterized by a high frequency of Carabelli's cusp on M1, six-cusped lower first molars, four-cusped lower second molars, and type 3 of the first eocone groove on the upper first molar. The frequency of the distal trigonid crest on M1, double shoveling, reduction of incisors (grade 1), hypocone reduction of maxillary second permanent molar, four-cusped lower first molars and the deflecting wrinkle is moderately higher in the population from the Armenian Highland (Classical period) that the average value for Georgian populations (Fig. 3).

\section{Comparative analysis}

Table 4 presents data concerning the frequency of the occurrence of 10 odontological traits in 11 populations of the Armenian Highland and Georgia. The frequency of traits in percents was converted into frequencies expressed as radians. A modified set of initial data was used to assess the degree of differentiation by means of principal component analysis. This method converts original traits (in radians) into new traits (meta-traits) that are called principal components. The principal component analysis reduces the multidimensional set of variety to two or three-dimensional level, losing only a small percent of information.

Taking into account the character of the connection between attributes in this component, it is possible to tell that the large values up to the first dimension axes

\begin{tabular}{|c|c|c|c|}
\hline Trait & I & II & III \\
\hline $\mathrm{I}^{1}-\mathrm{I}^{1}$ diastema & 0.597 & -0.324 & 0.745 \\
\hline $\mathrm{I}^{2}$ crowding & 0.541 & 0.116 & 0.117 \\
\hline $\begin{array}{l}\text { Hypocone re- } \\
\text { duction on } \mathrm{M}^{2}\end{array}$ & 0.494 & -0.746 & 0.351 \\
\hline $\begin{array}{c}\text { Carabelli cusp on } \\
\qquad \mathrm{M}^{1}\end{array}$ & -0.421 & 0.672 & 0.632 \\
\hline Four-cusped $\mathrm{M}_{1}$ & 0.979 & 0.501 & -0.492 \\
\hline Four-cusped $\mathrm{M}_{2}$ & -0.814 & -0.134 & 0.541 \\
\hline $\begin{array}{l}\text { Distal trigonid } \\
\text { crest }\end{array}$ & -0.158 & 0.689 & 0.221 \\
\hline $\begin{array}{l}\text { Deflecting wrinkle } \\
\text { of me-ta-conid }\end{array}$ & 0.771 & 0.352 & 0.426 \\
\hline 1 eo (3) $\mathrm{M}^{1}$ & 0.686 & 0.511 & -0.269 \\
\hline 2 med II M 1 & 0.501 & 0.203 & -0.462 \\
\hline Values & 54.561 & 28.671 & 20.352 \\
\hline
\end{tabular}

Table 4. Elements of three initial components for 11 groups 
(correspond to groups with four-cusped lower first molars (0.979), the deflecting wrinkle (0.771), the 1eo (3) $\mathrm{M}^{1}$ (0.686), diastema (I1-I1) (0.597), I2crowding (0.541), and 2 med II M1 (0.501). A negative weight is associated with four-cusped lower second molars (-0.814).

Maximal values for the second component $(28.6 \%$ of the total variability) are for distal ridge of the trigonid (0.689), the Carabelli cusp on the upper first molar (0.672), type 3 of the first eocone groove on the upper first molar (0.511), and four-cusped lower first molars (0.501). The negative weight is associated with hypocone reduction of the maxillary second permanent molar (-0.746). The third component accounts for $11.4 \%$ of intergroup variation. The strongest weights are with the diastema (I1-I1) (0.745), Carabelli cusp on the upper first molar (0.632), and four-cusped lower second molars (0.541).

For positive coordinates of the first axis, the most discriminating dental traits are the four-cusped lower first molars, the deflecting wrinkle, and type 3 of the first eocone groove of the upper first molar. The first two traits show higher frequencies in the Lchashen (3), Landjik, Black Fortress (1) and Beniamin, Vardbakh, Black Fortress I, and Karmracar (4) samples, and slightly lower frequencies in the groups from Georgia. For negative coordinates, the most significant trait is fourcusped lower second molars, which show higher frequencies in the groups from Georgia.

Next, we applied the cluster analysis (Fig. 5). Two main clusters are illustrated in the dendrogram, obtained by using hierarchic method from the first 3 axes. The first cluster is represented by Bronze Age samples from the Armenian Highland, differentiated from the second cluster composed of all the other groups. Within the latter, two sub-groups can be shown. The first is formed by the Bingel Dag (20th century Armenian) and the Feudal and Classical periods samples of Georgia. The Classical period sample can be chronologically placed between the Early Feudal Age and Middle Feudal Age periods. They may have maintained archaic traits because of their geographical isolation. The 2 supgroup consists of the Digomi, Mckheti (Bronze Age) and the Late Feudal Age samples.

From the analysis of non-metric dental traits, a common biological background can be hypothesized among the populations that inhabited Transcaucasian. The Armenian Highland groups perfectly fit this pattern, showing a high degree of biological continuity between the two periods (Bronze Age - Classical period). The 20th century Armenians (Bingel Dag) are strictly linked between the groups from Georgia (Feudal and Classical periods). Clear affinities are visible between the samples from Georgia.

Comparative analysis reveals that the populations of the Armenian Highland and Georgia differentiated as far as the frequency of odontological traits is concerned. Armenian Highland samples are characterised by a different frequency in trait reduction compared to the series from Georgia. Morphological traits of teeth (odontological traits) differentiated markedly between the comparative populations. Therefore, they provide a good tool for studying the biological differentiation of skeletal populations. Diachronic changes in nonmetric morphological characters of teeth in the Armenian highland and Georgia populations occurred at different rates for different traits.

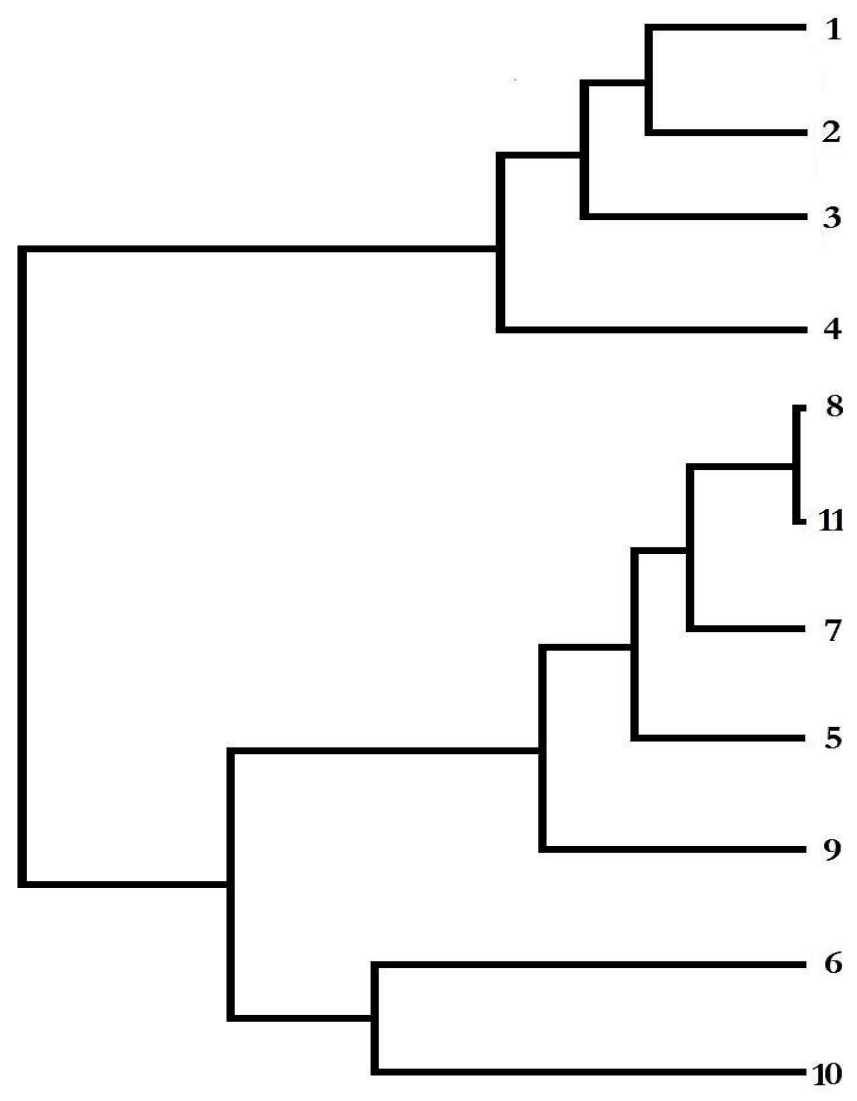

Fig. 5.

Cluster tree:

1 - Armenian Highland (Bronze Age),

2 - (Bronze Age and Classical period),

3 - Armenian Highland (Bronze Age), 4 - Armenian highland (Classical period), 5 - Armenian Highland (Modern population), 6 - Georgia (Bronze Age),

7 - Georgia (Classical period),

8 - Georgia (Early Feudal period),

9 - Georgia (Average Feudal period),

10 - Georgia (Late Feudal period), 11 - Georgia (Feudal period) 


\section{LITERATURE CITED}

Aksjanova GA. 1978. Some dental material in connection with the problem of the ancient populations of Northern Europe. J Hum Evol 7:525-528.

Alexeev VP. 1974. An origin of the people of Caucasus. Moscow: Science.

Alvesalo L, Osborne R, Kari M. 1975. The 47, XYY male, $Y$ chromosome, and tooth size. Am J Hum Genet 27:53-61.

Bagdasarova HA. 2000. Odontologic the characteristic of nomads Sauromatians and Sarmatians Age (on materials of burial ground Kazibaba). In: Rikushina GV, editor, Anthropological and ethnographic data on the population of Central Asia, Anthropological and ethnographic data on the population of Central Asia. Vol. 2. Moscow: Old garden, p 113-124.

Brace CL. 1963. Structural reduction in evolution. American Naturalist 97:185-195.

Brace CL. 1976. Krapina, 'classic' Neanderthals and the evolution of the European face. J Hum Evol 8:527550.

Brace CL. 1979. Tooth reduction in the Orient. Asian Perspectives 19:203-219.

Brace CL. 1980. Australian tooth-size clines and the death of the stereotype. Curr Anthropol 21: 141-153.

Brace CL, Mahler PE. 1971. Early Holocene changes in the human dentition. Am J Phys Anthropol 34:191204.

Brace CL, Rosenberg KR, Hunt KD. 1987. Gradual change in human tooth size in theLate Pleistocene and Early Holocene. Evolution 41:705-720.

Brose DS, Wolpoff M. 1971. Early Upper Paleolithic man and the late Middle Pleistoceneteeth. American Anthropologist 73: 1156-1194.

Brabant H, Twiesselmann F. 1964. Observations sur L'évolution de la denture permanente humaine en Europe occidentale. Bulletin du Groupe International des Recherches Scientifiques en Stomatologie 7:1184.

Calcagno JM. 1986. Dental Reduction in Early Holocene Nubia. Am J Phys Anthro-pol 70: 349-363.

Calcagno JM, Gibson KR. 1988. Human dental reduction: natural selection or the probablemutation effect. Am J Phys Anthropol 77: 505-517.

Chamla MC. 1980. Étude des variations métriques des couronnes dentaires des Nord-Africains del'Épipaléolithique à l'époque actuelle. L'Anthropologie 84:254 $-271$.

Coppa A, Cucina A, Lucci M, Mancinelli D, Vargiu R. 2007. The origins and spread of agriculture in Italy: a dental nonmetric analysis. Am J Phys Anthropol 133:918-930.

Cucina A, Lucci M, Vargiu R, Coppa A. 1999. Dental evidence of biological affinity and life conditions of prehistoric Trentino (Italy) samples from the Neolithic to the Early Bronze Age. Int J Osteoarch 6:404-416.

Dahlberg AA. 1963. Dental evolution and culture. Hum Biol 35: 237-249.

Donina (Khaldeeva) NI.1969. On some momentous diachronic changes of the human dentition (the medieval East Slavic and Russian crania series). Soviet Ethnography 2: 35-47.

Dutta PC. 1983. A Study of the Molar Teeth of the Bronze Age Harappans in the Context of Evolutionary Biology. Anthropologie 21(2): 97-102.

Edgar H, Lease L. 2007. Correlations between deciduous and permanent mandibular molars in a European-American sample. Am J Phys Anthropol 133:726734.

Frayer DW. 1977. Metric Dental Change in the European Upper Paleolithic and Mesolithic. Am J Phys Anthropol 46:109-120.

Frayer DW. 1978. Evolution of the Dentition in Upper Paleolithic and Mesolithic Europe . Lawrence: University of Kansas Publications in Anthropology 10.

Frayer DW. 1984. Biological and Cultural Change in the European Late Pleistocene and EarlyHolocene. In: Smith FH, Spencer F, editors, The Origins of Modern Humans: A World Survey of the Fossil Evidence. New York: Alan R. Liss, p 211-250.

Gadjiev YuM. 1979. Dagestan. Peoples of the Caucasus. In: Zubov AA, Khaldeeva NI, editors, Ethnic Odontology of the USSR. Moscow: Science, 141-163.

Gravere RU. 1999. Odontological aspect in ethnogenesis and ethnic history of Eastern Slavic peoples. In: Alexeeva TI, editor, Eastern Slavs. Anthropology and Ethnic history. Moscow: Scientific Worrld, p 205-219.

Grine FE. 1984. The deciduous dentition of the Kalahari San, the South African Negro and the South African Plio-Pleistocene hominids. Ph.D. dissertation. Johannesburg:. University of Witwatersrand. South Africa.

Grine FE. 1986. Anthropological aspects of the deciduous teeth of South African blacks. In: Singer RJ, Lundy, editors, Variation, culture and evolution in African populations. Johannesburg: Witwatersrand University Press, $\mathrm{p}$ 47-83.

Grine FE. 1990. Deciduous dental features of Kalahari San: comparisons of non-metrical traits. In: Sperber $\mathrm{GH}$, editor, From the apes to angels. New York: Wiley-Liss, p 153-169.

Godina EZ, Purundzhan AL, Homjakova IA. 2000. Diachronic transformation of body size and the heads of the Moscow children and adolescents as a criterion microevolution processes. In: Efimova SG, editor, The people of Russia: from past to present. Anthropology, Part II. Moscow: Old garden, 305-330.

Goose DH. 1971. The inheritance of tooth size in British 
families. In: Dahlberg AA, editor, Dental Morphology and Evolution. Chicago: University of Chicago Press, $\mathrm{p}$ 263-270.

Irish JD. 2005. Population Continuity vs. Discontinuity Revisited: Dental Affinities among Late Paleolithic Through Christian-Era Nubians. Am J Phys Anthropol 128:520-535.

Irish JD. 2006. Who Were the Ancient Egyptians? Dental Affinities among Neolithic Through Postdynastic Peoples. Am J Phys Anthropol 129:529-543.

Hanihara K. 1965. Some crown characters of the deciduous incisors and canines in Japanese-American hybrids. J Anthrop Soc Nippon 72:135-145.

Hanihara K. 1966. Mongoloid dental complex in the deciduous dentition. J Anthrop Soc Nippon 74:61-71.

Hanihara K. 1970. Mongoloid dental complex in the deciduous dentition, with special reference to the dentition of the Ainu. J Anthrop Soc Nippon 78: 3-17.

Hanihara K, Kuwashima T, Sakao N. 1964: The deflecting wrinkle on the lower molars in recent Japanese. J Anthrop Soc Nippon 72:1-8

Hanihara K, Minamidate T. 1965. Tuberculum accesorium mediale internum in the human deciduous lower second molars. J Anth Soc Nippon 73: 9-18.

Haydenblit R. 1996. Dental Variation among Four Prehispanic Mexican Populations. Am J Phys Anthropol 100:225-246.

Hawkey D. 1998.Out of Asia: dental evidence for affinities and microevolution of early populations from India/Sri Lanka. PhD thesis. Arizona State University.

Herodotus 1972. History in Nine Books. Translation and Notes by Stratanovsky GA. Leningrad: Science.

Hillson SW. 1996. Dental Anthropology. Cambridge: Cambridge University Press.

Howell TL, Kintigh KW. 1996. Archaeological Identifi cation of Kin Groups Using Mortuary and Biological Data: An Example from the American Southwest. American Antiquity 61:537-554.

Jørgensen K. 1956. The deciduous dentition: a descripttive and comparative anato-mical study. Acta Odont Scand 14: 1-202.

Johnson AL, Lovell NC. 1994. Biological differentiation at Predynastic Naqada, Egypt: an analysis of dental morphological traits. Am J Phys Anthropol 93:427433.

Kashibadze VF. 1990. Odontology of Armenians. Biological Journal of Armenia 4: 285-295.

Kashibadze VF. 2006. Odontological data for an anthropological history of the Cauca-sus. Ethnographic Reviews 5: 117-133.

Keiser JA. 1990. Human Adult Odontometrics. Cambbridge Studies in Biological Anthropology 4.Cambridge:
Kitagawa, Y., 2000. Nonmetric morphological characters of deciduous teeth in Japan: diachronic evidence of past 4000 years. Int J Osteoarch 10: 242-253.

Khaldeeva NI. 1979. Peoples of Siberia and the Far East. In: Zubov AA, Khaldeyeva NA, editors, Ethnic odon tology of the USSR. Moscow: Science, 187-211

Khaldeeva NI. 1992.Variations in the structure of teeth: theoretical and practical aspects of dentistry. In: Zubov AA, editor, Innovations in the technique and methodology of anthropological research. Series: Peo ples and Cultures.Vol. 10. Moscow, 147-182.

Khudaverdyan AYu. 2005. Atlas of paleopatological findings in the territory of Armenia. Yerevan: Van Aryan.

Khudaverdyan AYu. 2009. The bronze population of Armenian highland. Ethnogene-sis and ethnic histo ry. Yerevan: Van Aryan.

Khudaverdyan A. 2011a. Indo-European migrations: their origin from the point of view of odontology. The Anthropologist 13:75-81.

Khudaverdyan AYu. 2011b. Secular dental changes in the populations of the Armenian highland: evolutionary and ecological aspects. Archeology, Ethnography \& Anthropology of Eurasia 1:139-146.

Khudaverdyan A. 2011c. Artificial modification of skulls and teeth from ancient burials in Armenia. Anthropos 106: 602-609.

Kochiev RS. 1979. Peoples of the Caucasus, TransCaucasus and north Caucasus. In: Zubov AA, Khal deyeva NA, editors, Ethnic odontology of the USSR. Moscow: Science, 114-141.

Lease L. 2003. Ancestral determination of AfricanAmericans and European-Americans deciduous den tition using metric and non-metric analysis. Ph.D. dissertation. Ohio State University, Columbus, Ohio. Lease L, Sciulli P. 2005. Brief communication: discrimi nation between European-American and AfricanAmerican children based on deciduous metrics and morphology. Am J Phys Anthropol 126: 56-60.

Lukacs J, Hemphill B. 1991. The dental anthropology of pre-historic Baluchistan: a morphometric approach to the peopling of South Asia. In: Kelley M, Larsen CS, editors. Advances in dental anthropology. New York: Willey-Liss, p 77-119.

Lukacs JR, Walimbe SR. 1984. Deciduous dental mor phology and the biological affinities of a Chalcolithic skeletal series from Western India. Am J Phys An thropol 65: 23-30.

Minkov C. 1979 The anthropological and odontology icheskoe study of contemporary population of Bul garia. Unpublished Ph.D. dissertation. Moscow. Morris DH, Gladstone HS, Dahlberg AA. 1978. Utopremolar: the anthropology of a dental trait In: Butler PM, 
Pinhasi R. 1998. An odontometric investigation of the affinities of the Nazlet Khater specimen to prehistory ic, protohistoric and modern African populations. Dental Anthropology 12:2-10.

Pinto-Cisternas J, Moggi-Cecchi J, Pacciani E. 1995. A morphological variant of the permanent upper lat eral incisor in two Tuscan samples from different periods. In: Cecchi-Moggi J, editor, Aspects of dental biology: Paleonthology, anthropology and evolution.

Florence: International Institute for the Study of Man, $p$ 333-339.

Piotrovsky BB. 1959. Vansky kingdom (Urartu). Mos cow: East literature.

Potter RH, Nance WE, Yu P-L, Davis WB. 1976, A twin study of dental dimension. II.Independent genetic determinants Am J Phys Anthropol 44:397-412.

Rikushina GV, Dubova NA, Suvorova NA. 2003. Odon tologic characteristic of the ancient population of Turkmenistan (on materials of burial Bronze Age from Gonur-Depe). In: Aksyanova GA, editor, Sci ence the person and a society: results, problems, pro spects. Moscow, p 130-140.

Sasaki K, Kanazawa E. 1998. Morphological traits on dentino-enamel juction of lower deciduous molar series. In: Mayhall J, Heikkinen T, editors. Dental morphology 1998: 11th international symposium on dental morphology. Oulu, Finland: University of $\mathrm{Ou}$ lu, p 167-178.

Sciulli PW. 1998. Evolution of the dentition prehistoric Ohio Valley Native Americans: II. morphology of the deciduous dentition. Am J Phys Anthropol 106:189205.

Sciulli PW, Mahaney MC. 1991. Phenotypic evolution in prehistoric Ohio Amerindians:natural selection ver sus random genetic drift in tooth size reduction. Hum Biol 63:499- 511

Scott GR. 1973. Dental morphology: a genetic study of American White families and variation in living Southwest Indians, Ph.D. dissertation, Arizona State University.

Shapiro H L. 1963. The anthropologic backgrounds of dental and oral morphology. Oral Surg, Oral Medi cine and Oral Pathology 16 (4):458-465.

Smith FH. 1976. The Neandertal Remains from Krapina. Department of Anthropology, University of Tennes see, Report of Investigations 15, Knoxville, Tennes see.

Smith P. 1977. Regional variation in tooth size and pa thology in fossil hominids. Am J Phys Anthropol 47: 459-466

Smith P. 1978. Evolutionary changes in the deciduous dentition of Near Eastern populations. J Hum Evol 7: 401-408.

Smith PE, Koyoumdisky-Kaye Kalderon W, Stern D.
1987. Directionality of dental trait frequency between human second deciduous and first permanent mo lars. Arch Oral Biol 32:5-9.

Strabo 1964. The Geography XI, IV. Translation and Notes by Stratanowski G. Mos-cow: Science.

Sofaer JA 1970. Dental morphologic variation and the Hardy-Weinberg law.J Dent Res 49(6):1505-1508.

Sofaer JA, Smith P, Kaye E. 1986 Affinities Between Con -temporary and Skeletal Jewish and Non-Jewish Groups Based on Tooth Morphology. Am J Phys An thropol 70:265-275.

Suzuki M, Sakai T. 1956. On the "deflecting wrinkle" in recent Japanese. J Anthrop Soc Nippon 65: 49-53.

Tocheri M. 2002. The effect of sexual dimorphism, asym -metry and inter-trait associa-tion on the distribution of thirteen deciduous dental nonmetric traits in a sample of Pima Indians. Dental Anthropology 15:1-9.

Townsend GC, Brown T. 1978. Heritability of perma nent tooth size. Am J Phys Anthropol 49:497-505

Townsend GC, Brown T. 1981. The Carabelli trait in Australian aboriginal dentition. Arch Oral Biol 26:809 -814 .

Townsend GC, Yamada H, Smith P. 1986. The metacon ule in Australian aboriginals: an accessory tubercle on maxillary molar teeth. Hum Biol 58:851-862.

Townsend GC, Yamada H, Smith P. 1990. Expression of the entoconulid (sixth cusp) on mandibular molar teeth of an Australian aboriginal population. Am J Phys Anthropol 82:267-274.

Turner CG. 1969. Directionality in the canine field mod el. J Dent Res 48:1310.

Tur SS. 2009. Odontologic characteristic of population Andronovo culture from Altai. News of the Ural State University 4: 228-236.

Ullinger J. 2003. A comparison of morphological traits in deciduous and permanent dentition. Am J Phys Anthropol 36: 212.

Ullinger JR, Sheridan SG, Hawkey DE, Turner CG, Coo ley R. 2005. Bioarchaeolo-gical analysis of cultural transition in the southern Levant using dental non metric traits. Am J Phys Anthropol 128: 466-476.

Varela HH, Cocilovo JA. 2000. Structure of the Prehis toric population of San Pedro de Atacama. Curr An thropol 41:125-132.

y'Edynak G. 1989. Yugoslav Mesolithic dental reduc tion. Am J Phys Anthropol 78: 17-36

Vargiu R, Cucina A, Coppa A. 2009. Italian populations during the Copper Age: Assessment of biological affinities through morphological dental traits. Hum Biol 81:479- 493.

von Koenigswald GHR. 1952. Gigantopithecus blacki von Koenigswald, a giant fossil hominoid from the Pleistocene of Southern China. Anthrop Pap Am Mus Nat Hist 43(4):291-326. 
Weidenreich F. 1937. The dentition of Sinanthropus pekenensis: a comparative odontography of the hom inids. Paleontol Sin. D:1-180.

Wolpoff MH. 1971. Metric Trends in Hominid Dental Evolution: Studies in Anthropology . Case Western Reserve Press, Cleveland.

y'Edynak G. 1989. Yugoslav Mesolithic dental reduc tion. Am J Phys Anthropol 78: 17-36

Zubov A.A. 1968 . Odontology: A Method of Anthropo logical Research. Moscow: Science.

Zubov AA. 1973. Ethnic odontology. Moscow: Science.

Zubov AA. 1974. Odontoglyphics. In: Zubov AA, editor Racialgenetic processes in ethnic history. Moscow: Science, $\mathrm{p}$ 11-42.

Zubov AA. 1979. Conclusion. In: Zubov AA, Khalde yeva NA, editors, Ethnic odontology of the USSR. Moscow: Science. P. 229-254.

Zubov AA, Khaldeeva HA. 1989. Odontology in mod ern anthropology. Moscow: Nauka.

Zubova AV. 2008. Anthropological structure of the pop ulation of Western Siberia during epoch of the devel oped and Late Bronze. Ph.D. dissertation. Novosi birsk.

Zubova AV. 2010. The population of a Pit Grave culture al-historical generality in light odontologic data. Bul letin of archeology, anthropology and ethnography 2 (13):85-95. 